\title{
Child labour and wealth in rural Cambodia: Re-examination of alternative hypotheses
}

\author{
Fukui Seiichi ${ }^{1 *}$, Miwa Kana ${ }^{2}$ and Han Phoumin ${ }^{3}$ \\ ${ }^{1}$ Department of Natural Resource Economics, Graduate School of Agriculture, Kyoto University, Kitashirakawa, \\ Oiwake-cho, Sakyo-ku, Kyoto 606-8502, Japan. \\ ${ }^{2}$ Faculty of Economics, Kushiro Public University of Economics, 4-1-1, Ashino, Kushiro, Hokkaido 085-8585, Japan. \\ ${ }^{3}$ Greater Mekong Commission Secretariat, P. O. Box 6101, Unit 18 Ban Sithane Neua, Sikhottabong District, \\ Vientiane 01000, Lao PDR.
}

Accepted 16 September, 2011

\begin{abstract}
This study investigated whether the child labour prevailing in the rice-growing areas of Cambodia where wealth is measure in terms of cattle, can be explain by the poverty hypothesis and wealth paradox. In order to test if these hypotheses hold in all contexts, this study presented some evidences from rural Cambodia and used a Tobit model to investigate the impact of assets such as land and cattle on child labour. While field evidence showed no significant relationship between child labour and farmland size or income, this study found an inverse U-shaped relationship between the number of cattle owned by farmers and child labour hours. These findings suggest that the poverty hypothesis and the wealth paradox do not support the evidence on child labour supply in rural Cambodia.
\end{abstract}

Key words: Child labour, poverty hypothesis, wealth paradox, inverse U-shaped relationship, Cambodia.

\section{INTRODUCTION}

To discuss the policies designed to cope with the negative impacts of child labour on human capital accumulation, it is important to understand that there are various types of child labour depending on the contexts. Our observations on child labour in rural Cambodia are not consistent with the existing hypotheses on child labour supply, such as the poverty hypothesis and the wealth paradox. This paper aim at empirically explaining why child labour prevailing in rural Cambodia cannot be explain by these two hypotheses.

The poverty hypothesis, which states that poverty is the fundamental determinant of the incidence of child labour, is widely supported in literature (Basu and Tzannatos, 2003; Edmonds, 2007; Bacolod and Ranjan, 2008; Bhalotra, 2007). However, some studies did not find evidence supporting this hypothesis (Bhalotra and Heady,

${ }^{\star}$ Corresponding author. E-mail: seifukui@kais.kyoto-u.ac.jp. Tel: 81-75-753-6292.
2003; Canagarajah and Coulombe, 1997; Edmonds and Turk, 2002; Ganglemair, 2006; Kanbargi and Kulkarni, 1991; Nielsen, 1998; Ray, 2000; Rosenzweig and Evenson, 1977; Shafiq, 2007).

Bhalotra and Heady (2003) found a positive relationship between child labour and landholding in a rural setting; they termed their findings the 'wealth paradox'. Ganglemair (2006) and Kanbargi and Kulkarni (1991) found evidence that the number of cattle owned by a household has a positive correlation with the incidence of child labour. The wealth paradox suggests a positive monotonic relationship between child labour and wealth or income. However, it is quite possible that the number of hours worked by children reduces as household income or wealth increases beyond a threshold.

Basu et al. (2010) felt that an explicit model of the labour market was missing, thus they developed a model that suggested an inverse U-shaped relationship between landholding and child labour, assuming two versions of the poverty hypothesis (Basu and Van, 1998; Dumas, 
2007). One indicated that parents do not send their children to work if they can afford not to, and the other ('luxury axiom') indicated that child leisure is a good luxury. They found empirical evidence in India that supports the hypothesis derived from the theoretical model. However, some recent studies suggested that the inverse U-shaped relationship can be explained by an alternative hypothesis. Dumas (2007) found that child leisure is not a good luxury but just a normal good and child labour supply is not constrained by subsistence in rural Burkina Faso. Del Carpio (2008), in his model, assumed that there were no factor markets and excluded the poverty hypothesis, and found an inverse U-shaped relationship between child labour and income in Nicaragua.

In addition, as Basu et al. (2010) mentioned, different forms of wealth have different employment potential and hence will have different effects on child labour. For example, in the mid- Himalayan region where Basu et al. (2010) found an inverse U-shaped relationship, land is such a crucial complement of labour in the rural area that land may influence child labour decisively. However, in a different geographical and agro- ecological condition where most studies on child labour and wealth focused on other forms of wealth such as cattle, the wealth may have a crucial effect on child labour. We need to examine whether Basu et al. (2010) hypothesis holds in regions with different geographical and agro-ecological conditions.

As will be clear in the subsequent sections, we could not find any evidence supporting the poverty hypothesis, inverse U-shaped relationship between child labour and land and wealth paradox in rain-fed lowland rice-growing areas, which cover $80 \%$ of the agricultural land in Cambodia, a country characterized by poverty and a high incidence of child labour. Most people living in this area consider livestock, particularly cattle, as a measure of wealth, since it is much easier for most rice-growing farmers who own small farmlands ( 0.35 ha on average) to get cattle than to obtain land (Asian Population and Development Association, 2007). Therefore, these people tend to hold cattle as wealth, as a source of income, and to cope with exogenous shock. Although raising cattle plays an important role in farm life, it demands considerable investment in terms of family labour, and children are considered most suitable for this type of work.

The main objectives of this paper are (1) to show that the wealth paradox, or the inverse U-shaped relationship between child labour and landholding is not consistent with the evidence obtained from rural Cambodia and (2) to examine whether we can find and explain an inverse U-shaped relationship between child labour and cattle holding without assuming the 'luxury axiom'. However, some factors need to be considered. First, since there is a large number of non-working children in our study area, the Tobit model was used. Second, the number of cattle in a household and the number of hours worked by children can be determined simultaneously. To deal with a biased estimator and endogeneity problems caused by taking into consideration non-working children and cattle holding as an important indicator of wealth for rural households, this study deviates from the approach used in existing studies and uses the simultaneous Tobit model proposed by Datt and Ravallion (1994).

The rest of this paper is organized in the following manner. The characteristics of the sample villages and households in this study area as described and an exploration of the imperfections in the land, credit, and labour markets; imperfections in these markets were considered to have a huge bearing on the relationship between child labour and wealth (Basu et al., 2010; Bhalotra and Heady, 2003). Based on these findings, conceptual framework was described. Then, the twostage Tobit model was derived for testing the hypotheses and an empirical study was conducted using the household data collected from four villages located in rain-fed rice-growing areas in Cambodia. Finally, the conclusion was presented.

\section{CHARACTERISTICS OF MARKETS AND HOUSEHOLDS IN THE STUDY AREA}

\section{Characteristics of the surveyed villages and households}

In an attempt to assess the socioeconomic characteristics of rain-fed rice-growing areas in Cambodia, a field survey was conducted in four villages in Kampong Speu and Takeo provinces. These four villages were randomly selected from 150 villages targeted by the Rural Development and Resettlement Project (RDRP), jointly implemented by the Japan International Cooperation Agency (JICA) and the Cambodian government (Rural Development Project, 2004). Kampong Speu and Takeo were selected as the project areas since they are located within 50 to $100 \mathrm{~km}$ of each other and were easily accessible.

The survey was conducted in September 2006, which was a lean farming season. A random sampling method was employed for selecting samples from a list of households in the village; the village head maintain the list. 168 households were sampled, of which 46 were located in KD village, 41 in $P C$ village, 45 in $K K$ village, and 36 in TK village. In addition, semi-structured interviews were conducted and qualitative and quantitative questions were used to obtain background information and specific characteristics of the households and individuals. These constituted the primary field survey aimed at obtaining the socioeconomic data of households; the data pertained to several aspects such as farming systems, household consumption, migrations, agricultural child labour, child health, and social capital. 
Table 1. Characteristics of the surveyed villages.

\begin{tabular}{|c|c|c|c|c|}
\hline \multirow{2}{*}{$\begin{array}{l}\text { Characteristics } \\
\text { Villages }\end{array}$} & \multicolumn{2}{|c|}{ Kampong Speu province } & \multicolumn{2}{|c|}{ Takeo } \\
\hline & $\mathrm{KD}$ & $\mathrm{PC}$ & $\mathrm{KK}$ & TK \\
\hline Number of households in the sample & 46 & 41 & 45 & 36 \\
\hline Farming households (\%) & 95.6 & 95.1 & 95.5 & 88.8 \\
\hline Arable land per $\mathrm{HH}\left(\mathrm{m}^{2}\right)^{*}$ & 11.049 & 6.111 & 7.160 & 5.508 \\
\hline Irrigated land (\%) & n.a. & n.a. & 30 & n.a. \\
\hline Number of household members per $\mathrm{HH}$ per household (person) ${ }^{*}$ & 4.50 & 4.85 & 4.62 & 5.28 \\
\hline Average household income (riel/year) ${ }^{\star}$ & 2.646 .799 & 2.177 .413 & 3.116 .004 & 3.304 .018 \\
\hline Agricultural income (riel/year) ${ }^{*}$ & 967.365 & 760.108 & 1.636 .040 & 759.952 \\
\hline Non-agricultural income (riel/year) ${ }^{*}$ & 950.456 .5 & 875.019 & 979.009 & 1.996 .209 \\
\hline Remittance and others (riel/year) ${ }^{*}$ & 728.978 & 542.286 & 500.956. & 547.758 \\
\hline Per capita income (riel/year) ${ }^{*}$ & 588.178 & 448.951 & 674.460 & 625.761 \\
\hline Households below poverty line (\%) & 63.04 & 80.49 & 57.78 & 61.11 \\
\hline Household-owned cattle per HH (head). including calves* & 2.26 & 2.05 & 3.22 & 1.75 \\
\hline Family labour per $\mathrm{HH}$ (no. of people) $)^{*}$ & 2.98 & 2.68 & 2.64 & 2.89 \\
\hline Paddy yield $(\mathrm{t} / \mathrm{ha})^{*}$ & 1.97 & 2.69 & 2.34 & 2.14 \\
\hline
\end{tabular}

Source: Rural Household Survey, 2006. *, Mean value of the sample households.

The 168 households interviewed comprised 200 children aged 5 to 14 years (101 girls and 99 boys). The four villages are located in typical rain-fed rice-growing areas, where paddy is the main crop and vegetables are a supplementary source of income. The average yields were low, 1.5 to $2.5 \mathrm{t} / \mathrm{ha}$, and are unstable in rain-fed conditions. KK village was the only one that was partially irrigated.

In all four villages, farmers cultivate paddy in the rainy season and vegetables such as cucumber, watermelon, and water spinach in the early dry season. In addition, the farm size is small and family labour is relatively abundant (Table 1). Therefore, farmers do not use capital-intensive technology such as tractors and threshing machines, but labour-intensive technology such as cattle for cultivation and a hand-operated thresher. Farmers raise approximately two heads of cattle, one for cultivation and one for savings. Agricultural productivity is low and local job opportunities are limited. Therefore, over half the households subsist below the poverty line.

The socioeconomic status of KK and KD villages is better than that of PC and TK. Approximately $30 \%$ of the arable land in KK village is irrigated from a reservoir, which has the capacity to provide water for cultivating the main crop in both seasons. Thus, vegetables and fruits are abundantly grown in this area. Further, KD village has superior land quality and larger farm size than the other three villages.

\section{Characteristics of the markets}

The theoretical models developed by Bhalotra and Heady (2003) and Basu et al. (2010) imply that imperfections in the credit, land, and labour market play an important role in achieving a positive, or inverse U-shaped, relationship between child labour and landholdings. Therefore, the imperfections in land, credit, and labour markets in our study area need to be investigated in order to consider the underlying theoretical model for empirical analysis. The credit market is not considered perfectly competitive. This is because, formal credit arrangements such as microcredit with collateral, group lending, quasi-credit, or informal ones such as exchange of gifts between relatives or friends (Table 2), are set up to cope with the risks posed by uncertain agricultural production, information asymmetry between lenders and borrowers, and moral hazards. If the credit market is perfectly competitive and functions smoothly, such arrangements are not required. However, the villagers have easy access to loans when needed. Credit from various microcredit institutions as well as zero-interest loan from relatives or friends is available (Table 2). The labour market in our study area is also not considered perfectly competitive. The farmers in this area tend to employ exchange labour rather than hired labour (Table 3), although farmers can easily find hired labour. This is because market wage rates are higher than the cost of exchange labour, which must be equivalent to the opportunity cost of substituting family labour with exchange labour. This implies that market wage is higher than the imputed cost of family labour, and suggests that there exists surplus labour and constraints on the market demand for family labour in our study area. This evidence is supported by the fact that the annual number of working days of adult family labourers is approximately 111 days on average, excluding the time spent on domestic chores (888 h). This is much less than the average number of working days of salaried workers in Cambodia (240.7 days or $8 \mathrm{~h}$ /day; World Bank, 2010). In 
Table 2. Credit market in the study area: Source of loans and interest rates.

\begin{tabular}{|c|c|c|c|c|c|c|c|c|}
\hline \multirow{3}{*}{ Source of loan } & \multicolumn{8}{|c|}{ Village } \\
\hline & \multicolumn{2}{|c|}{ KD } & \multicolumn{2}{|r|}{ PC } & \multicolumn{2}{|c|}{ KK } & \multicolumn{2}{|c|}{ TK } \\
\hline & $\begin{array}{l}\text { Interest } \\
\text { rate (\%) }\end{array}$ & $\begin{array}{c}\text { Number of } \\
\text { contracts }\end{array}$ & $\begin{array}{l}\text { Interest } \\
\text { rate (\%) } \\
\end{array}$ & $\begin{array}{c}\text { Number of } \\
\text { contracts }\end{array}$ & $\begin{array}{l}\text { Interest } \\
\text { rate (\%) }\end{array}$ & $\begin{array}{c}\text { Number of } \\
\text { contracts }\end{array}$ & $\begin{array}{l}\text { Interest } \\
\text { rate (\%) }\end{array}$ & $\begin{array}{c}\text { Number of } \\
\text { contracts }\end{array}$ \\
\hline \multicolumn{9}{|c|}{ Microfinance institution } \\
\hline With collateral & $3 \% / \mathrm{m}$ & 28 & $3 \% / \mathrm{m}$ & 4 & $3 \%-4 \% / m$ & 19 & $3 \% / \mathrm{m}$ & 12 \\
\hline Without collateral & & 0 & $10 \% / y$ & 3 & & 0 & & 0 \\
\hline Group lending & & 0 & & 0 & & 0 & $1.6 \% / \mathrm{m}$ & 5 \\
\hline $\begin{array}{l}\text { Relatives, friends, } \\
\text { and neighbours }\end{array}$ & 0 & 11 & 0 & 22 & 0 & 15 & $\begin{array}{c}0 \\
3.5 \% / \mathrm{m} \\
2.5 \% / \mathrm{m}\end{array}$ & $\begin{array}{l}4 \\
3 \\
1\end{array}$ \\
\hline \multicolumn{9}{|l|}{ Others } \\
\hline Traders & $35 \% / y$ & 1 & & 0 & $\begin{array}{c}6.25 \% / \mathrm{m} \\
6.7 \% / \mathrm{cs}\end{array}$ & $\begin{array}{l}1 \\
1\end{array}$ & & 0 \\
\hline Moneylenders & & & $\begin{array}{c}10 \% \\
5 \% / m\end{array}$ & $\begin{array}{l}1 \\
5\end{array}$ & & & & \\
\hline Government & & & $\begin{array}{l}10 \% / \mathrm{m} \\
3.5 \% / \mathrm{m}\end{array}$ & $\begin{array}{l}1 \\
1\end{array}$ & & & $3 \% / \mathrm{m}$ & 1 \\
\hline Total & & 40 & & 37 & & 36 & & 26 \\
\hline
\end{tabular}

Source: Rural Household Survey, 2006; $m$ = month, $y=$ year; $c s$ = crop season.

Table 3. Labour market in the study area: Hired and exchange labour.

\begin{tabular}{lccccc}
\hline & \multicolumn{5}{c}{ Village } \\
\cline { 2 - 6 } \multicolumn{1}{c}{ Labour } & KD & PC & KK & TK & Total \\
\cline { 2 - 6 } & 12 & 15 & 9 & 1 & 37 \\
Used hired labour & 25 & 9 & 12 & 20 & 66 \\
Used exchange labour & 25 & &
\end{tabular}

Source: Rural Household Survey, 2006.

addition, from our interview with farmers, it was found that they could easily hire adult labourers at the market wage rate, but they found it difficult to hire child labourers because most children worked for their respective families. This evidence implies that the child labour market is non-existent in our study area, a view shared by Basu et al. (2010), while the adult labour market, where the demand for adult labour is limited, exists. In our study area, there are few tenancy transactions and the land tenancy market is dominated by share tenancy contracts (Table 4). The facts that share tenancy is a predominant form of land tenancy and that personal relations such as kinship between the landowner and tenant is an important determinant of the contractual form, suggest that land market transactions are difficult because of extremely high transaction costs caused by uncertainty and asymmetric information. This is because if the land tenancy market is perfect, the landowner and tenant do not select the share tenancy contract, and the contract is not necessarily between relatives (Otsuka et al., 1992; Sadoulet et al., 1997).

\section{Characteristics of child labour}

Children are mostly involved in cattle rearing, fishing, and domestic chores, none of which is considered harmful to children, provided the labour hours are not too long. Data from the interview with children showed that a majority of them neither work with pesticides nor operate machinery. Of all the children in our sample, 85 were non-working and 115 were working. This study adopted the definition of a working child as presented in the Cambodia Child Labour Survey, 2001. According to this definition, economic and non-economic activities by children aged 5 to 14 years constitute child labour. Here, economic activities include work in industries such as agriculture, fishery, manufacturing, trade, and non-economic activity is mainly work for housekeeping. Children of this age group involved in such activities for even one hour in the past one week are considered as working children.

Tables 5 and 6 present the characteristics of child labour in the sample households. As can be seen, the children are involved in various areas of economic activity, 
Table 4. Land tenancy market in the study area.

\begin{tabular}{lccccc}
\hline \multirow{2}{*}{ Type of contract } & \multicolumn{5}{c}{ Village } \\
\cline { 2 - 6 } & \multirow{2}{*}{ Land rent } & KD & PC & KK & TK \\
\cline { 2 - 6 } & & \multicolumn{4}{c}{ Number of contracts } \\
\hline \multirow{2}{*}{ Share tenancy } & $50: 50$ & 1 & 0 & 4 & 1 \\
Land pawning & $60: 40$ & 1 & 0 & 0 & 0 \\
Leasehold & & 0 & 1 & 0 & 0 \\
\hline
\end{tabular}

Source: Rural Household Survey, 2006; 50:50 and 60:40 indicate the rate of sharing between tenant and landowner.

Table 5. Child labourers aged 5 to 14 years.

\begin{tabular}{lc} 
Number of children & 200 \\
Rate of female child labour (\%) & 51 \\
Frequency of child labour participation (\%) & \\
Male & 51 \\
Female & 64 \\
\hline
\end{tabular}

Source: Rural Household Survey, 2006.

such as rice farming, cattle rearing, and domestic chores. The rate of female child labour was found to be $64 \%$, and that of male child labour, 51\%. This is because female children more frequently help their parents in domestic chores and take care of younger siblings (Table 8). The average weekly working hours for both male and female children are almost the same: approximately 8.5 and 8.9 $h$, respectively (Table 9). No significantly positive or negative relationship was found between land size and children's working hours in the week prior to the interview conducted in the lean farming season, but a positive relationship was found in the peak farming season. On the other hand, a positive relationship was found between the number of cattle owned and hours worked by children during the lean farming season, while no significant relationship was found in the peak season. Our findings for the peak season are consistent with the wealth paradox for landholding, but not for cattle holding. Further, no significant difference was observed between hours worked by children of households under the poverty line and those above the poverty line for both the lean and peak farming seasons.

This finding is not consistent with the luxury axiom. In addition, this study showed that the number of hours worked by a child is positively correlated with the child's age (Table 6).

\section{TESTING ALTERNATIVE HYPOTHESES}

\section{Theoretical framework for the incidence of child labour}

To investigate the relationship between child labour and household wealth or income, a static unitary household model was developed. In this model, households maximize the expected utility with respect to labour supply. This study assumes an imperfection in the adult labour market: the demand for adult family labour is limited. It also assumes that there is no land market and that households have three sources of income: farming, off-farm jobs, and cattle rearing. Under the assumption of non-existent land and labour markets, this study supposes that the optimal child labour supply, adult labour supply, and number of cattle are derived by the following household utility maximization behaviour.

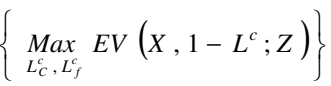

$$
\begin{aligned}
& X=\theta Y\left(A, T, H, L_{f}\right)+C_{0}\left\{1+\eta\left(L_{c}\right)\right\} \\
& L^{c}=L_{C}^{c}+L_{f}^{c}, \\
& L_{C}=\gamma(C H) \cdot L_{C}^{c}, L_{f}=\gamma(C H) \cdot L_{f}^{c}
\end{aligned}
$$

Where $X$ refers to the income and $A$ refers to household assets, excluding land and cattle. This study assumes that $A$ is non-liquid and can be used as collateral. Further, $T$ refers to the owned land area. $H$ refers to the resource endowment of adult human capital, which comprises educational level, number of family labourers, and age of family labourers. $Y$ is the household income excluding the income from cattle rearing, which is determined by adult human capital endowment, household assets, land ownership, and child labour for farming. Here, we assume that the number of cattle does not affect $Y$ because we could not find any statistically significant relationship between the number of cattle and household income. $\theta$ is a multiplicative random parameter with mean value 1 and variance value, $\sigma_{\theta}^{2}, \eta$ is the physical return from cattle rearing in terms of weight gain and offspring (Shapiro, 1979) and is a function of labour hours used for cattle rearing $\left(L_{C}\right) . Z$ is a vector of other family characteristics such as female household head. $C_{0}$ is the number of cattle that is assumed to be exogenous, and to be affected by land 
Table 6. Working hours of child labourers aged 5 to14 years.

\begin{tabular}{|c|c|c|c|}
\hline \multirow{3}{*}{ Working hours } & & \multicolumn{2}{|c|}{ Type of child labour } \\
\hline & & \multirow{2}{*}{$\begin{array}{c}\text { Working hours per week } \\
\text { (weekly hours/child) } \\
\end{array}$} & \multirow{2}{*}{$\begin{array}{c}\text { Working hours in peak season }^{1)} \\
\text { (yearly hours/child) }\end{array}$} \\
\hline & & & \\
\hline \multirow{2}{*}{ Gender } & Male & 8.5 & \\
\hline & Female & 8.9 & \\
\hline \multirow{5}{*}{ Age } & $5-6$ years & 0 & 0 \\
\hline & $7-9$ years & 3.3 & 9.7 \\
\hline & $10-12$ years & 10.9 & 96.8 \\
\hline & $13-14$ years & 15.6 & 103.7 \\
\hline & 14 years & 18.5 & 132.4 \\
\hline \multirow{2}{*}{ Land size $^{\dagger}$} & Less than $7000 \mathrm{~m}^{2}$ & 13.3 & 44.6 \\
\hline & $7000 \mathrm{~m}^{2}$ or more & 14.0 & $73.8^{* *}$ \\
\hline \multirow{2}{*}{ Cattle } & Less than 2 heads & 9.16 & 52.7 \\
\hline & 2 heads or more & $12.6^{\star *}$ & 69.8 \\
\hline Below or above & Below poverty line (\%) & 8.8 & 57.3 \\
\hline Poverty line & Above poverty line (\%) & 10.2 & 48.5 \\
\hline
\end{tabular}

Source: Rural Household Survey, 2006. ${ }^{*}$ and ${ }^{* *}$ denote statistical significance at the 10 and $5 \%$ levels respectively. ${ }^{\dagger}$ The operated farmland size of each household. ${ }^{\S} \mathrm{Cattle}$ holding is calculated in terms of mature cattle. ${ }^{1)}$ The duration of the peak season ranges from 1 week to 2.5 months.

and asset sizes, however, this exogeneity assumption must be tested. $L^{c}$ is the total labour supply of children. $L_{C}$ is the total labour supply of children for cattle rearing. $L_{C}^{c}$ and $L_{f}^{c}$ represent the child labour supply for cattlerearing and other children's work such as farming and household chores (henceforth, 'farming'), respectively. In addition, the efficiency of child labour for cattle rearing and farming is assumed to be dependent on children's characteristics $(\mathrm{CH})$ such as age and gender. $\gamma$ is an indicator of efficiency $(0 \leq \gamma \leq 1)$ and is an increasing function of $\mathrm{CH}$. The total demand for adult labour is assumed to be constrained. This study also assumes that the labour endowment of children is equal to 1 , and $1-L_{C}$ is their leisure or schooling time. The utility function $V$, income excluding cattle rearing $Y$, and the physical return from the herding function $\eta$ are increasing and strictly concave functions, with $V_{X}>0$, $V_{X X}<0, \quad V_{1-L}>0, V_{1-L 1-L}<0, \quad Y_{L}>0, \quad Y_{L L}<0$, $\eta_{L}>0$, and $\eta_{L L}<0$.
Here, $X$ and $L$ represent income and labour input respectively.

If the optimal solutions of $C_{0}, L_{C}^{c}$, and $L_{f}^{c}$ are interior $C_{0}$ can be derived as a function of all exogenous variables- $A, T, H, Z, C H$-and an indicator of yield variance (here, $\rho$ is used as a proxy); moreover, $L_{C}^{c}$ and $L_{f}^{c}$ can be derived as functions of a given $C_{0}$ and the exogenous variables $H, Z$, and $C H$. However, if $L_{C}^{c}$ or $L_{f}^{c}$ is constrained, it may be equal to 0 .

In particular, if the adult labour endowment is large relative to land, asset, and number of cattle, or if the marginal disutility of child labour is sufficiently large, it is quite possible that children do not need to work in farming and on cattle rearing. In such a case, $L_{C}^{c}$ and $L_{f}^{c}$ are equal to zero. The first-order condition can be derived from the first utility maximization problem. Since this study focuses on cattle and land, by taking total differentials with respect to $C_{0}$ and $T$ and rearranging the terms, the following were obtained:

$$
\frac{d L^{c}}{d C_{0}}=-\frac{\left[-\left\{\left(E V_{X X} C_{0} \eta_{L_{c}} \gamma-V_{1-L^{c}, X}\right)(1+\eta)+E V_{X} \eta_{L c}\right\}\left(E V_{X} Y_{L_{f}{ }^{c} L_{f}^{c}}\right)+\left(E V_{X X} \theta Y_{L_{f}^{c}}-E V_{1-L^{c} X}\right)(1+\eta)\left(E V_{X} \eta_{L_{c} L_{c}} \gamma\right)\right]}{\left[\left\{E V_{X X} \cdot V_{1-L^{c}, 1-L^{c}}-\left(E V_{X \cdot 1-L^{c}}\right)^{2}\right\}\left(C_{0} \eta_{L_{c}} \gamma-Y_{L_{f}^{c}}\right)^{2}\right]}
$$




$$
\frac{d L^{c}}{d T}=-\frac{\left[-\left(E V_{X X} C_{0} \eta_{L_{c}{ }^{c}} \gamma-V_{1-L^{c}, X} Y_{T}\right)\left(V_{X} Y_{L_{f}{ }^{c} L_{f}^{c}}\right)-\left\{E\left(V_{X X} Y_{L_{f}{ }^{c} T}+V_{X} Y_{L_{f}{ }^{c} T}-V_{1-L^{c}, X} Y_{T}\right)\right\}\left(V_{X} C_{0} \eta_{L_{c}{ }^{c} L_{c}} \gamma^{2}\right)\right]+\left(d L^{c} / d C_{0}\right)\left(d C_{0} / d T\right)}{\left[\left\{E V_{X X} \cdot V_{1-L^{c}, 1-L^{c}}-\left(E V_{X \cdot 1-L^{c}}\right)^{2}\right\}\left(C_{0} \eta_{L_{c}} \gamma-Y_{L_{f}{ }^{c}}\right)^{2}\right]}
$$

The denominator of both equations is positive because the second-order condition is assumed satisfied. Therefore, for cattle, if the marginal utility of income earned by cattle rearing by children $\left(E V_{X} \cdot \gamma \cdot \eta_{L_{C}}\right)$ is larger than the sum of the income effects on the marginal utility of child leisure $\left(E V_{1-L, X}\right)$ and the marginal utility of income earned by cattle rearing by children $\left\{-\left(E V_{1-L_{c}, X}\right)+\left(E V_{X X} \cdot \gamma \cdot \eta_{L_{c}} \cdot C_{0}\right)\right\}$, and if the negative effect of cattle on child farming labour (the second term of the numerator) is relatively small, the sign of $d L^{c} / d C_{0}$ is positive; otherwise, it is negative. Therefore, if the marginal utility of child labour decreases and income effect increases as the number of hours worked by a child increases an increase in the number of cattle first leads to an increase and then to a decrease in the hours worked by children. This implies that our model can explain the inverse $U$-shaped relationship between child labour supply and the number of cattle owned.

As for land area, we have to take into account the effect of land area on the number of cattle $\left(d L^{c} / d C_{0}\right.$ )$\cdot\left(d C_{0} / d T\right)$. If the land area has a positive effect on the number of cattle $\left(d C_{0} / d T\right)$, we can explain the effect of land size on child labour in the manner similar to the case of cattle. However, if $d C_{0} / d T$ is negative, the effect of land area on child labour through the impact of land area on cattle rearing may offset the direct effect of land area on child labour. In such a case, the effect of land size on child labour $\left(d L^{c} / d T\right)$ is unclear.

From our theoretical model, the following child labour demand function can be derived:

$$
\begin{aligned}
& L^{C^{*}}=L_{C}\left(C_{0}^{*}, A T, H Z, C H, \rho\right) \quad \text { if } W\left(C_{0}^{*}, A T, H Z, C H, \rho, d\right) \leq W\left(C_{0}^{*}, A T, H Z, C H, \rho L^{c}\right) \\
& L^{c *}=0 \quad \text { if otherwise }
\end{aligned}
$$

Here, $W$ is the optimal level of household welfare. $C_{0}^{*}$ is the optimal number of cattle and is expressed as $C_{0}(A, T, H, Z, C H, \rho)$ if $C_{0}$ is not constrained. If $C_{0}$ is constrained by the upper limit $B^{-}$determined by the sizes of land and non-land asset because feed grass and financial fund necessary for holding cattle largely depend on the sizes of land and non-land asset, $C_{0}{ }^{*}$ is expressed as a function of $A$ and $T$.

\section{Empirical model}

Based on the aforementioned theoretical framework, the following econometric models are formulated to test the alternative hypotheses on the incidence of child labour. Child labour demand function:

$$
\begin{aligned}
& L_{i}^{c}=\alpha_{6}+\alpha_{1} \cdot A+\alpha_{2} \cdot(A)^{2}+\alpha_{3} \cdot T+\alpha_{4} \cdot(T)^{2}+\alpha_{5} \cdot H+\alpha_{6} \cdot Z+\alpha_{4} \cdot \rho+\alpha_{8} \cdot C H+\alpha_{5} \cdot C_{0}+\mathcal{E} \\
& \text { if } L_{i}^{c}>0, \quad(i=c, f), \\
& L^{c}=0 \quad \text { if } \quad L^{c *}=0 .
\end{aligned}
$$

In the above equations $A, T, \rho, L^{c}, C_{0}, H, Z$, and $\mathrm{CH}$ are defined as in the previously, and $\varepsilon$ is a disturbance term. Here, following Basu et al. (2010), $\left(C_{0}\right)^{2}$ is added as an explanatory variable for testing the inverse U-shaped relationships between child labour, and number of cattle owned and area of land held.

To estimate these models, the Tobit (censored) model was used, since the data includes zero-value dependent variables and observations on explanatory variables for all the samples are available. The cattle- rearing function without a constraint is formulated in the following manner:

$$
\begin{gathered}
C_{0}=\beta_{0}+\beta_{1} \cdot A+\beta_{2} \cdot(A)^{2}+\beta_{3} \cdot T+\beta_{4} \cdot(T)^{2}+\beta_{5} \cdot H+\beta_{6} \cdot Z \\
+\beta_{7} \cdot \rho+\beta_{8} \cdot C H+\mu
\end{gathered}
$$

However, some households do not own any cattle. Therefore, it may be necessary to use the Tobit model to estimate not only child labour demand but also the number of cattle owned by households.

In such a case, it is necessary to devise methods to obtain a consistent estimator in the event that the endogeneity problem exists with regard to cattle. From among the explanatory variables, the number of cattle, $C_{0}$, is expected to be an endogenous variable because it is simultaneously determined with child labour demand. To cope with the endogeneity problem, following Datt and Ravallion (1994; Appendix 1), Equation (3) is estimated using the Tobit model and the residuals are obtained; thereafter, the residuals of $C_{0}$ is input into Equation (2) as an additional regressor, and the consistent estimators for each parameter are obtained. The generalized estimator proposed by Datt and Ravallion (1994) is consistent for the simultaneous Tobit model with censored endogenous variables and a triangular matrix of structural coefficients like the econometric model used in this paper.

If the results of testing exogeneity indicate that the null hypothesis, which states that the number of cattle is an exogenous variable, cannot be rejected, a simple Tobit model is used for estimation. However, the simple Tobit model is not necessarily suitable if the problems of bias 
Table 7. Descriptive statistics.

\begin{tabular}{llcc}
\hline Variable & Definition & M & SD \\
\hline Child labour hours & Hours worked in the past 7 days & 8.66 & 12.22 \\
Number of cattle & Number of cattle, including calves ${ }^{\dagger}$ (head) & 2.23 & 1.39 \\
(Number of cattle) $^{2}$ & Square of number of cattle & 6.9 & 7.94 \\
Age of child & Age of child (months) & 122.88 & 32.99 \\
Gender of child & $=1$ if female, = 0 otherwise & 0.66 & 0.5 \\
Mother's education & Mother's education (year) & 3.15 & 2.63 \\
Father's education & Father's education (year) & 5.24 & 3.28 \\
Female household head & $=1$ if female head, = 0 otherwise & 0.07 & 0.25 \\
Self-health assessment & $=0$ if often, = 1 if occasionally, = 2 if seldom & 1.84 & 0.7 \\
& suffered from ill health & & \\
Family labour & Number of adult family labourers who live & 3.26 & 1.68 \\
Land & together & 6.85 & 5.27 \\
(Land) $^{2}$ & Owned land (1000 m ${ }^{2}$ ) & 72.63 & 106.20 \\
Asset & Square of owned land & 10.10 & 7.95 \\
(Asset) $^{2}$ & Asset excluding land (million riel) $)^{1)}$ & 164.94 & 252.89 \\
Instrumental variables (IVs) & Square of asset excluding land & & \\
KK village dummy & $=1$ if KK village, = 0 otherwise & 0.28 & 0.45 \\
Agricultural income ratio & Share of agricultural income to total income & 0.45 & 0.36 \\
\hline
\end{tabular}

Source: Author's calculation, ${ }^{\dagger}$ Calves are converted into mature cattle by a conversion ratio of 0.5 to 1 mature cattle, ${ }^{1)}$ 'Asset' includes the values of farm assets, house, bank deposit, gold, jewellery, car, and other durable goods, but it excludes the value of land.

caused by hetero-skedasticity or non-normal distribution exist. Therefore, normality and homoskedasticity is tested when a simple Tobit model is applied. Thereafter, if nonnormality or heteroskedasticity is observed, certain econometric methodologies suitable for solving the problems caused by non-normality or heteroskedasticity are applied.

\section{Empirical estimation}

The detailed descriptions of all the variables used for the estimation are provided in Table 7. This study estimated the two-stage Tobit model for child labour in the lean season and found that the hypothesis of the exogeneity of the number of cattle cannot be rejected for child labour. To test the exogeneity, we used the KK village dummy and the ratio of agricultural income to total income as instrumental variables. We suppose that the $\mathrm{KK}$ village dummy is positively correlated with the number of cattle because KK village is endowed with a relatively abundant resource of grass feed and that agricultural income, mainly rice income, is supposed to be positively correlated with the number of cattle because the larger the rice field, the larger the demand for draft animals. On the other hand, we cannot find any reason why there exists any correlation between the disturbance of child labour and these variables. In addition, we did not use the other village dummies as instrumental variables because the estimated coefficients of those variables are insignificant and the effects on estimation results are negligible. As for why cattle variable is exogenous, one possibility is that households hold cattle for the purpose of savings, investment, or agricultural production. Therefore, the decisions for these activities are made from the long-term perspective, and hence, cattle holding are decided independent of child labour hours.

Therefore, a simple Tobit model is applied and the hypotheses of non-normality and homoskedasticity are tested. The test results are presented in Table 9. To test the normality assumption in the censored regression model, both the conditional moment test (using a chisquare value) by Pagan and Vella (1989) and the linear model test by Chesher and Irish (1987) were employed. The results of both test statistics, presented in the upper portion of Table 9, indicate that the null hypothesis of normality is rejected; thus, it can be stated that nonnormality exists in the simple Tobit estimation of the child labour demand function. To test for heteroskedasticity in the Tobit model, two likelihood-based tests, the likelihood ratio and the Wald test, are applied. This study assumes that the number of cattle, its squared value, age of the child, sex of household head, health assessment, and the number of family labourers are heteroskedastic variables. 
Table 8. Estimation results of the child labour demand function in lean farming season.

\begin{tabular}{|c|c|c|c|c|c|c|}
\hline \multirow{3}{*}{\begin{tabular}{|l} 
Model \\
Dependent variable \\
Explanatory variable
\end{tabular}} & \multicolumn{2}{|c|}{ Two-stage Tobit model } & \multicolumn{2}{|c|}{ Simple Tobit model } & \multicolumn{2}{|c|}{ CLAD } \\
\hline & Child labour I & cond stage) & Child lab & hours & Child lab & hours \\
\hline & Coefficient & $t$-value & Coefficient & $t$-value & Coefficient & $t$-value \\
\hline Constant & $-59.68^{* \star \star}$ & -6.86 & $-58.65^{\star \star \star}$ & -6.89 & $-18.61^{\star \star *}$ & -3.95 \\
\hline Number of cattle & $11.08^{* *}$ & 2.94 & $9.69^{* * *}$ & 3.11 & $3.53^{\star *}$ & 2.08 \\
\hline (Number of cattle) $^{2}$ & $-2.22^{\star \star \star}$ & -3.19 & $-1.99^{\star \star \star}$ & -3.32 & $-0.61^{* *}$ & -2.18 \\
\hline Child age & $0.37^{* * *}$ & 8.39 & $0.37^{* * *}$ & 8.38 & $0.17^{* * *}$ & 6.60 \\
\hline Female child & -0.55 & -0.23 & -0.52 & -0.22 & -0.65 & -0.41 \\
\hline Mother's education & $1.27^{\star \star}$ & 2.48 & $1.37^{\star * *}$ & 2.77 & $0.84^{\star \star \star}$ & 2.57 \\
\hline Father's education & 0.03 & 0.71 & 0.02 & 0.06 & -0.002 & -0.01 \\
\hline Female household head & $-11.34^{*}$ & -1.89 & $-11.65^{\star}$ & -1.95 & $-6.35^{*}$ & -1.77 \\
\hline Health assessment & $4.97^{\star \star}$ & 2.60 & $5.32^{* * *}$ & 2.86 & $3.59^{\star \star \star}$ & 2.86 \\
\hline Family labour & -0.62 & -0.61 & -0.81 & -0.83 & -0.40 & -0.63 \\
\hline Land & 0.38 & 0.50 & 0.42 & 0.57 & -0.06 & -0.12 \\
\hline$(\text { Land })^{2}$ & -0.02 & -0.50 & -0.02 & -0.53 & 0.001 & -0.06 \\
\hline Asset & -0.11 & -0.17 & -0.04 & -0.07 & -0.04 & -0.11 \\
\hline$(\text { Asset })^{2}$ & 0.00 & 0.02 & -0.0004 & -0.03 & -0.001 & 0.08 \\
\hline (Number of cattle)_residuals & 1.26 & 0.05 & - & & - & \\
\hline [(Number of cattle)_residuals $]^{2}$ & -0.08 & -0.23 & - & & - & \\
\hline Sigma & 14.10 & & 14.14 & & 10.07 & \\
\hline Log-likelihood & -475.48 & & -475.77 & & -523.05 & \\
\hline No. of observations & 200 & & 200 & & 200 & \\
\hline
\end{tabular}

Source: Author's calculation. ${ }^{*},{ }^{* *}$, and ${ }^{* * *}$ denote statistical significance at the 10,5 and $1 \%$ levels, respectively.

From Table 9, it is evident that the homoskedastic hypothesis is rejected by the likelihood ratio test. However, the Wald test statistic indicates that homoskedasticity cannot be rejected in the simple Tobit model. It is well known that when there are multiple heteroskedastic variables, the Wald test is a more appropriate procedure for testing heteroskedasticity. Therefore, this study concludes that the errors of the simple Tobit model used are homoskedastic. In the simple Tobit model used for estimating the child labour demand function, as mentioned above, the normality hypothesis is rejected, but the homoskedasticity hypothesis is not. The next step is to cope with the nonnormality problem. For this purpose, this study estimates the censored least absolute deviations (CLAD) model, which is a method for obtaining a consistent estimation of coefficients under non-normality. The estimation result of CLAD is presented in the third column in Table 8.

\section{Number of cattle}

The coefficients of the number of cattle and its squared value are statistically significant and show an inverse Ushaped relationship between child labour and cattle holding in any model. This relationship indicates that children will be required to work more as the number of cattle owned increases, but only up to 2.5 mature cattle. Therefore, the wealth paradox, which states that greater wealth leads to a higher incidence of child labour, holds for a certain range of cattle in the context of rural Cambodia.

\section{Land size and assets}

The coefficients of farmland size, assets, and their squared values are statistically significant with regard to the number of cattle owned; moreover, land and asset have an inverse U-shaped relationship with the number of cattle, as is evident from Appendix A. However, the coefficients of farmland size and asset in the equation of the simple Tobit model for determining the child labour demand function are not significant although they imply an inverse U-shaped relationship (Appendix A). There is no inevitability for a significant relationship between asset and child labour. A possible reason landholding does not have a positive relationship with child labour is as follows: In farming, child labour is used mainly for harvesting. In the harvesting season, however, household members must rear their cattle while the adult members are busy with harvesting. In such cases, child labour is used for cattle rearing as well as harvesting. Therefore, the hours worked by children do not necessarily increase as land size increases. The inverse U-shaped relationship between child labour and cattle holding indicates that landholding and asset holding indirectly affect child labour through cattle holding. The coefficients of the 
Table 9. Tests for non-normality and heteroskedasticity.

\begin{tabular}{lcc}
\hline Non-normality test & Test statistic & p-value \\
\hline Conditional moment test & $396.61^{\star * *}$ & 0.00 \\
LM test & $23.06^{* * *}$ & 0.00 \\
& & \\
Heteroskedasticity test & & \\
Log-likelihood ratio test & $14.11^{* *}$ & 0.03 \\
Wald test & 0.57 & 1.00 \\
\hline
\end{tabular}

Source: Author's calculation. ${ }^{* *}$ and ${ }^{* * *}$ denote statistical significance at the 5 and $1 \%$ levels respectively

village dummy variable and agricultural income ratio have significantly positive impacts on cattle holding, while they do not affect child labour significantly. This implies that better conditions for feeding cattle in KK village and the risk posed by instable crop production translate to larger cattle holding, which in turn has an impact on child labour.

\section{Other variables related to wealth or income}

With regard to the other explanatory variables related to wealth or income, mother's education, female household head, child age, and child's heath condition have a significant effect on child labour. The positive effect of mother's education differs from evidence accumulated worldwide (Bhalotra and Heady, 2003; Deb and Rosati, 2004; Ray, 2000). These studies found a negative relationship between mother's education and the likelihood that a child will work. However, more recently, Shafiq (2007) showed that mother's education has a positive impact not only on in households where the child is sent to school but also where the child goes to school as well as works. Our finding that mother's education has a positive impact on child education (Miwa et al., 2010) is consistent with the situation in Bangladesh, as found by Shafiq (2007), as well as with our observation that mothers with higher educational attainment tend to work more outside the household and substitute child labour for their own labour at home. ${ }^{8}$ The coefficient of female household head is negatively significant. The number of family labourers and father's education do not have significant effects on child labour.

\section{Characteristics of children}

The coefficient of the age of children is positively significant. This implies that as a child grows older, he/she grows physically stronger and works more. The results do not evince gender differences in child labour. Since the variable of self-health assessment indicates how children are likely to suffer from ill health and higher values indicate that children are less likely to suffer from ill health, there is a positive relationship between child labour and health status. This implies that the healthier the children, the more they tend to work. These findings are plausible and can be verified.

\section{Conclusion}

This paper investigated the poverty hypothesis and wealth paradox using data collected from rice-growing areas in Cambodia. Studies have suggested that land and labour markets were not perfectly competitive and that household income does not affect the incidence of child labour. Therefore, this paper investigated the impact of wealth such as land, cattle, and other forms of wealth on child labour.

Our findings that the number of cattle owned by farmers has an inverse U-shaped relationship with the incidence of child labour are contrary to Bhalotra and Heady's (2003) finding that a positive relation exists between the two variables. Our finding is also contrary to Basu et al. (2010) findings that an inverse U-shaped relationship exists between child labour and farmland size, assuming 'luxury axiom'.

Considering the results discussed previously, it can be concluded that the poverty hypothesis or wealth paradox for landholding is not supported in this study; however, the inverse U-shaped relationship hypothesis for cattle without 'luxury axiom' in the context of poor rice-growing areas in Cambodia is supported. These findings have a policy implication on reducing child labour. Some policies, such as legal restrictions on child labour are considered to have little effect, because the majority of working children in developing countries work on family-run farms (Bhalotra and Heady, 2003). However, if child labour increases with household income as the wealth paradox implies, some policy measures for poverty reduction such as microcredit, income transfer increase the assets of poor households and child labour may reach a point that it becomes harmful for a child's human capital accumulation.

We can draw some implications on this argument from our findings. If the cattle count goes beyond 2.5 heads of mature cattle, child labour declines; this threshold is higher than the average number of cattle heads (2.23) in our survey area. This indicates that if the number of cattle owned by farmers' increases beyond a certain point, child labour can decrease.

In the context of rain-fed lowland rice-growing areas; which occupy the largest agricultural area in Cambodia and where cattle is more easily obtainable than land, and children are mainly engaged in light work such as cattle rearing, fishing, and domestic chores; our findings suggest that child labour may not have a negative effect on child health and schooling (Miwa et al., 2010). Parents depend on child labour because their income is not sufficient to meet family needs. Therefore, the direct measures employed for reducing child labour, such as 
establishing guidelines and monitoring, are neither necessary nor realistic in Cambodia's rain-fed lowland areas.

Thus, when assessing whether legal restrictions on child labour is the right intervention, we need to examine the context in which child labour prevails. This paper aims to contribute towards a better understanding of such contexts, particularly in the case of Cambodia, where labour laws have not yet been extended to the familybased agricultural sector (World Bank, 2006).

\section{Notes}

1. The Cambodia Child Labor Survey 2001 to 2002 found that there were approximately 1.5 million children, aged 5 to 14 years, who can be considered as 'working children'; in other words, approximately $44.8 \%$ of the children in this age group are working. This ratio is considerably high compared to that in other developing countries. Further, approximately $84.4 \%$ of Cambodia's working children live in rural areas, where households depend mainly on rice farming. The survey also found that not a few children of households living below the poverty line went to schools, while a good number of households living above the poverty line sent their children to work (Han, 2007).

2. It is common to find villagers in our study areas sell their assets, including cattle, to cope with unpredictable shocks such as crop failure and disease. From July 2008 to September 2009, 164 sample households who faced these shocks 174 times managed to cope with the shocks 60 times by selling their assets.

3 . We used the total poverty line $(\$ 0.44)$ for rural areas, estimated by the National Institute of Statistics, Cambodia, based on the Cambodia Socio-economic Survey, 2004.

4. Equal exchange of labour; wherein if one household provides its family labour to another household, the gesture is reciprocated the same way; is common in our study areas.

5. The results of the two-stage Tobit estimation are presented in Table 5 (for the results of the first-stage coefficient estimators (Appendix A). The estimation results for child labour in the peak season are similar to those in the lean season (Appendix B). Therefore, we do not elaborate on this.

6 . The estimation results are presented in the second column in Table 5.

7. Using LIMDEP, econometric software, the linear model statistic for the normality test can be calculated automatically.

8. This was obtained from our interviews with farmers.

\section{ACKNOWLEDGMENTS}

The field survey was financially supported by the Japan Society for the Promotion of Science and the Graduate
School of International Cooperation Studies, Kobe University.

\section{REFERENCES}

Asian Population and Development Association (2007). Impact of population movement on agricultural and rural development in the Kingdom of Cambodia: Case studies in Phnom Penh and Svay Rieng provinces. A report submitted to Japan's Ministry of Agriculture, Forestry and Fishery, Tokyo, Japan (in Japanese).

Bacolod MP, Ranjan P (2008). Why children work, attend school, or stay idle: the roles of ability and household wealth. Econ. Dev. Cultural Change 56:791-828.

Basu K, Das S, Dutta B (2010). Child labor and household wealth: theory and empirical evidence of an inverted-U. J. Dev. Econ. 91:814

Basu K, Tzannatos Z (2003). The global child labour problem: what do we know and what can we do? World Bank Econ. Rev. 17:147-173.

Basu K, Van PH (1998). The economics of child labour. Am. Econ. Rev. 88:412-427.

Bhalotra S (2007). Is child work necessary. Oxford Bull. Econ. Stati. 69:29-55.

Bhalotra S, Heady C (2003). Child farm labour: the wealth paradox. The World Bank Econ. Rev. 17:197-227.

Canagarajah S, Coulombe H (1997). Child labour and schooling in Ghana. Policy Research WP, No. 1844, World Bank, Washington, DC.

Chesher A, Irish M (1987). Residual analysis in the grouped and censored normal linear model. J. Econ. 34:33-61.

Datt G, Ravallion M (1994). Income gains for the poor from public works employment: evidence from two Indian villages. LSMS Working Paper No. 100, World Bank, Washington DC.

Deb P, Rosati F (2004). Estimating the effects of fertility decisions on child labour and schooling: A joint research project of the ILO, World Bank and Unicef.

Del Carpio X (2008). Does child labor always decrease with income? An evaluation in the context of a development program in Nicaragua. The World Bank, Policy Research Working Series. p. 4694.

Dumas C (2007). Why do parents make their children work? A test of the poverty hypothesis in rural areas of Burkina Faso. Oxford Econ. Pap. 59:301-329.

Edmonds VE (2007). Child labor. In: Strauss J and Schultz TP (Eds.). The Handbook of Development Economics North Holland. Amsterdam 4:3607-3709. Edmonds E, Turk C (2002). Child labour in transition in Vietnam. World Bank Policy Research World Bank, Washington DC. p. 2774.

Ganglemair B (2006). Intrinsic motivation, discrimination and the child labor-schooling trade-off: some empirical findings. Working paper, University of Bonn, Germany.

Han P (2007). Child labor, poverty and human capital: a study of Cambodia. Ph.D. dissertation, Kobe University.

Kanbargi R, Kulkarni PM (1991). Child labor in Tamil Nadu. In: R. Kanbaraki (Ed.). Child labor in the Indian subcontinent, Sage, New Delhi.

Miwa K, Han P, Fukui S (2010). Does child labour have a negative impact on child education and health? A case study in rural Cambodia. Oxford Dev. Stud. 38:357-382.

Nielsen HS (1998). Child labor and school attendance: two joint decisions. CLC-WP 98-15, Centre for Labor Market and Social Research, Aarhus, Denmark.

Otsuka K, Chuma H, Hayami Y (1992). Land and labor contracts in agrarian economies: theories and facts. J. Econ. Literature 30:19652018.

Pagan A, Vella F (1989). Diagnostic tests for models based on individual data: a survey. J. Appl. Econometrics 4:S29-59.

Rural Development Project (2004). Rural Development Project: Project Evaluation Report. Supported by UNOPS, Asian and Pacific Regional Office, Kuala Lumpur, Malaysia.

Ray R (2000). Child labor, child schooling and their interaction with adult labor: empirical evidence for Peru and Pakistan. World Bank 
Econ. Rev. 14:347-67.

Rosenzweig MR, Evenson RE (1977). Fertility, schooling, and the economic contribution of children in rural India: an econometric analysis. Econometrica 45:1065-1079.

Sadoulet E, de Janvry A, Fukui S (1997). The meaning of kinship in sharecropping contracts. Am. J. Agric. Econ. 79:394-406.

Shafiq MN (2007). Household schooling and child labor decisions in rural Bangladesh. J. Asian Econ. 18:946-66.

Shapiro K (1979). Livestock production and marketing in the entente states of West Africa: summary report. University of Michigan, Ann Arbor, Michigan.
World Bank (2006). Children's work in Cambodia: a challenge for growth and poverty reduction, Human Development Sector Report. p. 38005.

World Bank(2010), Cambodia-Doing Business 2010: Reforming through Different Terms. 


\section{APPENDIX}

Appendix A. Estimation results of the cattle function and tests of the independent variables (IVs).

\begin{tabular}{|c|c|c|c|c|}
\hline \multirow{3}{*}{$\begin{array}{l}\text { Model } \\
\text { Dependent variable } \\
\text { Independent variable } \\
\end{array}$} & \multicolumn{2}{|c|}{ Tobit model (First stage) } & \multicolumn{2}{|c|}{$\begin{array}{c}\text { Tobit model (include IVs for the first stage } \\
\text { Tobit estimation) }\end{array}$} \\
\hline & \multicolumn{2}{|c|}{ Number of cattle } & \multicolumn{2}{|c|}{ Child labour hours } \\
\hline & Coefficient & t-value & Coefficient & t-value \\
\hline Constant & -0.40 & -0.81 & $-58.57^{\star * *}$ & -6.78 \\
\hline Number of cattle & & & $9.70^{\star * *}$ & 3.11 \\
\hline (Number of cattle)2 & & & $-1.99^{\star \star \star}$ & -3.30 \\
\hline Age of child & 0.01 & 1.77 & $0.37^{\star \star *}$ & 8.32 \\
\hline Gender of child & 0.07 & 0.45 & -0.50 & -0.21 \\
\hline Mother's education & $0.11^{* * *}$ & 3.40 & $1.37^{* * *}$ & 2.76 \\
\hline Father's education & -0.02 & -0.76 & 0.02 & 0.05 \\
\hline Female household head & 0.29 & 0.77 & $-11.64^{*}$ & -1.91 \\
\hline Health assessment & -0.17 & -1.28 & 5.33 & 2.84 \\
\hline Family labour & -0.05 & -0.68 & -0.81 & -0.83 \\
\hline Land & $0.17^{\star \star *}$ & 3.40 & 0.43 & 0.57 \\
\hline (Land)2 & $-0.01^{* * *}$ & -2.71 & -0.02 & -0.53 \\
\hline Asset & $0.13^{* \star *}$ & 3.05 & -0.03 & -0.05 \\
\hline (Asset)2 & $-0.003^{\star \star \star}$ & -2.68 & -0.001 & -0.04 \\
\hline \multicolumn{5}{|l|}{ Instrumental variable } \\
\hline KK village dummy & $0.54^{\star *}$ & 2.54 & -0.10 & -0.34 \\
\hline Agricultural income ratio & $0.70^{\star \star *}$ & 2.71 & -0.29 & -0.08 \\
\hline Sigma & 1.13 & & 14.14 & \\
\hline Log-likelihood & -293.41 & & -475.77 & \\
\hline Total observation & 200 & & 200 & \\
\hline
\end{tabular}

Source: Author's calculation; ${ }^{*},{ }^{* *}$, and ${ }^{* * *}$ denote statistical significance at the 10,5 , and $1 \%$ level respectively.

Appendix B1. Estimation results of the child labour demand function in peak farming season.

\begin{tabular}{|c|c|c|c|c|c|c|}
\hline \multirow{3}{*}{$\begin{array}{l}\text { Model } \\
\text { Dependent variable } \\
\text { Explanatory variable } \\
\end{array}$} & \multicolumn{2}{|c|}{ Two-stage Tobit model } & \multicolumn{2}{|c|}{ Simple Tobit model } & \multicolumn{2}{|c|}{ CLAD } \\
\hline & \multicolumn{2}{|c|}{ Child labour hours (Second stage) } & \multicolumn{2}{|c|}{ Child labour hours } & \multicolumn{2}{|c|}{ Child labour hours } \\
\hline & Coefficient & $t$-value & Coefficient & $t$-value & Coefficient & $t$-value \\
\hline Constant & $-14.13^{\star \star \star}$ & -5.11 & $-14.25^{\star * *}$ & -5.19 & $-14.25^{\star \star \star}$ & -5.19 \\
\hline Number of cattle & $2.88^{\star *}$ & 2.28 & $3.07^{\star * *}$ & 2.86 & $3.07^{\star * *}$ & 2.86 \\
\hline (Number of cattle) $^{2}$ & $-0.64^{\star *}$ & -2.71 & $-0.67^{\star \star \star}$ & -3.17 & $-0.67^{\star \star *}$ & -3.17 \\
\hline Child age & $0.12^{* * *}$ & 7.77 & $0.12^{* * *}$ & 7.88 & $0.12^{* * *}$ & 7.88 \\
\hline Female child & -0.19 & -0.24 & -0.19 & -0.25 & -0.65 & -0.25 \\
\hline Mother's education & $0.34^{*}$ & 1.96 & $0.33^{* *}$ & 1.97 & $0.33^{* *}$ & 1.97 \\
\hline Father's education & $-0.273^{*}$ & -1.92 & $-0.27^{*}$ & -1.93 & $-0.27^{\star}$ & -1.93 \\
\hline Female household head & $-5.44^{* *}$ & -2.41 & $-5.43^{\star *}$ & -2.40 & $-5.43^{* *}$ & -2.40 \\
\hline Health assessment & 0.98 & 1.55 & 0.94 & 1.54 & 0.94 & 1.54 \\
\hline Family labour & $-0.77^{\star *}$ & -2.23 & $-0.75^{\star \star}$ & -2.29 & $-0.75^{\star \star}$ & -2.29 \\
\hline Land & 0.04 & 0.17 & 0.03 & 0.13 & 0.03 & 0.13 \\
\hline$(\text { Land })^{2}$ & -0.00 & -0.22 & -0.002 & -0.19 & -0.002 & -0.19 \\
\hline Asset & 0.02 & 0.11 & -0.03 & -0.16 & -0.03 & -0.16 \\
\hline$(\text { Asset })^{2}$ & 0.00 & 0.12 & -0.001 & -0.16 & -0.001 & -0.16 \\
\hline (Number of cattle)_residuals & -0.12 & -0.19 & - & & - & \\
\hline$[(\text { Number of cattle }) \text { residuals }]^{2}$ & -0.00 & -0.02 & - & & - & \\
\hline
\end{tabular}


Appendix B1. Contd.

\begin{tabular}{lccc}
\hline Sigma & 4.59 & 4.60 & 4.60 \\
Log likelihood & -329.77 & -329.81 & -329.81 \\
Number of observations & 200 & 200 & 200 \\
\hline
\end{tabular}

Source: Author's calculation. *, **, and ${ }^{* * *}$ denote statistical significance at the 10,5 , and $1 \%$ levels respectively.

Appendix B2. Tests for non-normality and heteroskedasticity.

\begin{tabular}{lcc}
\hline Non-normality test & Test statistic & p-value \\
\hline Conditional moment test & $731.26^{\star \star \star}$ & 0.00 \\
Linear model test & 3.07 & 0.22 \\
Heteroskedasticity test & & \\
Log-likelihood ratio test & 9.34 & 0.16 \\
Wald test & -3.07 & - \\
\hline
\end{tabular}

Source: Author's calculation. ${ }^{* *}$ and ${ }^{* *}$ denote statistical significance at the $5 \%$ and $1 \%$ levels respectively.

Appendix B3. Estimation results of the cattle function and tests of independent variables (IVs).

\begin{tabular}{|c|c|c|c|c|}
\hline \multirow{3}{*}{$\begin{array}{l}\text { Model } \\
\text { Dependent variable } \\
\text { Independent variable }\end{array}$} & \multicolumn{2}{|c|}{ (First stage) Tobit model } & \multicolumn{2}{|c|}{$\begin{array}{l}\text { Tobit model(include IVs for the } \\
\text { first stage Tobit estimation) }\end{array}$} \\
\hline & \multicolumn{2}{|c|}{ Number of cattle } & \multicolumn{2}{|c|}{ Child labour hours } \\
\hline & Coefficient & $t$-value & Coefficient & $t$-value \\
\hline Constant & -0.40 & -0.81 & $-14.24^{\star \star *}$ & -5.18 \\
\hline Number of cattle & & & $2.98^{* * *}$ & 2.84 \\
\hline${\text { (Number of cattle })^{2}}^{2}$ & & & $-0.62^{* * *}$ & -3.02 \\
\hline Age of child & 0.01 & 1.77 & $0.12^{\star * \star}$ & 7.89 \\
\hline Gender of child & 0.07 & 0.45 & -0.17 & -0.21 \\
\hline Mother's education & $0.11^{* \star *}$ & 3.40 & $0.32^{*}$ & 1.95 \\
\hline Father's education & -0.02 & -0.76 & $-0.25^{\star}$ & -1.74 \\
\hline Female household head & 0.29 & 0.77 & $-4.84^{\star *}$ & -2.09 \\
\hline Health assessment & -0.17 & -1.28 & $1.03^{*}$ & 1.68 \\
\hline Family labour & -0.05 & -0.68 & $-0.80^{* *}$ & -2.45 \\
\hline Land & $0.17^{\star \star \star}$ & 3.40 & 0.05 & 0.19 \\
\hline$(\text { Land })^{2}$ & $-0.01 * * *$ & -2.71 & -0.004 & -0.35 \\
\hline Asset & $0.13^{* * *}$ & 3.05 & 0.02 & 0.09 \\
\hline$(\text { Asset })^{2}$ & $-0.003^{\star * *}$ & -2.68 & -0.0003 & -0.06 \\
\hline \multicolumn{5}{|l|}{ Instrumental variable } \\
\hline KK village dummy & $0.54^{\star \star}$ & 2.54 & -1.38 & -1.32 \\
\hline Agricultural income ratio & $0.70^{* * *}$ & 2.71 & -0.37 & -0.30 \\
\hline Sigma & 1.13 & & 4.57 & \\
\hline Log-likelihood & -293.41 & & -328.84 & \\
\hline Total observation & 200 & & 200 & \\
\hline
\end{tabular}

